\title{
Role of Small Finance Banks in the Inclusive Growth of our Economy
}

\author{
Kittu R S ${ }^{1}$, Dr. Smt. Mahananda B Chittawadagi ${ }^{2}$
}

${ }^{1}$ Research Scholar,Department of Commerce KLE Society's S. Nijalingappa College Rajaji Nagar, Bangalore- 560010.

${ }^{2}$ Associate Professor and Research Guide Department of Commerce KLE Society's S. Nijalingappa College Rajaji Nagar, Bangalore- 560010.

\begin{tabular}{|c|c|}
\hline ARTICLE INFO & ABSTRACT \\
\hline \multirow[t]{4}{*}{$\begin{array}{l}\text { Keywords: } \\
\text { Financial Inclusion, } \\
\text { Differentiated } \\
\text { Banking License, } \\
\text { Banking Sector } \\
\text { Reforms, Digital } \\
\text { Banking, Risk } \\
\text { Management, } \\
\text { Payment Banks and } \\
\text { Small Finance } \\
\text { Banks }\end{array}$} & $\begin{array}{l}\text { It is estimated that globally over } 2.5 \text { billion people are excluded } \\
\text { from access to financial services of which one third is in India. } \\
\text { Though the reach and scope of banking has thus increased, the huge } \\
\text { demand for financial services remains insatiate. It is a matter of } \\
\text { concern that even with } 150 \text { domestic commercial banks comprising } \\
19 \text { Public Sector Banks, } 20 \text { Private Sector Banks, } 44 \text { Foreign Banks, } \\
4 \text { Local Area Banks, } 56 \text { Regional Rural Banks and over } 2,700 \text { Co- } \\
\text { operative Banks operating in the country, just about } 40 \text { per cent of } \\
\text { the adults have formal bank accounts }{ }^{1} \text {. }\end{array}$ \\
\hline & $\begin{array}{l}\text { To widen the scope of the banking sector reforms, the Centre } \\
\text { focused on financial inclusion, digital banking and better risk } \\
\text { management. Various initiatives have been taken by Reserve Bank } \\
\text { of India for strengthening the financial inclusion. One such } \\
\text { initiative is the issue of Differentiated Banking Licenses to financial } \\
\text { institutions to convert themselves into either Payment Banks or } \\
\text { Small Finance Banks. RBI issued in-principle approval to start } 11 \\
\text { Payment Banks and } 10 \text { Small Finance Banks. }\end{array}$ \\
\hline & $\begin{array}{l}\text { Financial inclusion plays a major role in inclusive growth of the } \\
\text { country. The growth of our economy is dependent on the growth of } \\
\text { the rural India. The availability of quality financial services in rural } \\
\text { areas will enable the large number of rural households to fund the } \\
\text { growth of their livelihoods. }\end{array}$ \\
\hline & $\begin{array}{l}\text { The present paper focuses on the study of Small Finance Banks and } \\
\text { their role in promoting financial inclusion in India. }\end{array}$ \\
\hline
\end{tabular}




\section{Introduction}

The origin of the current approach to financial inclusion can be traced to the United Nations initiatives, which broadly described the main goals of inclusive finance as access to a range of financial services including savings, credit, insurance, remittance and other banking/ payment services to all 'bankable' households and enterprises at a reasonable cost.

Financial inclusion may be defined as the process of ensuring access to financial services and timely and adequate credit where needed by vulnerable groups such as weaker sections and low income groups at an affordable cost (The Committee on Financial Inclusion, Chairman: Dr. C. Rangarajan).

Financial Inclusion refers to universal access to a wide range of financial services at a reasonable cost. These include not only banking products but also other financial services such as insurance and equity products (The Committee on Financial Sector Reforms, Chairman: Dr.Raghuram G. Rajan).

Efforts for financial inclusion started with the nationalization of 14 commercial banks in July 1969 and 6 commercial banks in 1980. With a view to provide more banking services in rural areas, regional rural banks were established in 1975. To enhance more access to financial services by rural population, post liberalization banking reforms started to take place in April 2010, which includes issue of universal and differentiated banking licenses.

To deepen the financial inclusion process and to undertake digital banking, Reserve Bank of India issued differentiated banking licenses (in-principal approval) to:

- Payments Banking license to 11 players - August 2015

- Small Finance Banking license to 10 players - September 2015

Differentiated bank license policy is the new form of guidelines by the RBI inviting individuals/entities to start either small finance banks or payment banks. These are different licenses in contrast to the existing conventional banks (like SBI, AXIS, ICICI etc).

The existing conventional banks, including public and private sector can provide all banking services and products. While differentiated banks like payment banks and small finance banks can provide only select banking services and products. RBI has adopted differentiated banking 
license policy to promote financial inclusion and to enable quick payment services using new banking technologies.

\section{Rationale of the Study}

The efforts of financial inclusion by the Centre and RBI are increasing day by day. The Government of India is spending the large sum of money for bringing every citizen of our country to the formal banking sector through various schemes of financial inclusion like JAM, (Jan Dhan, Adhaar and Mobile Banking). RBI has issued the Differentiated Banking Licenses to various micro finance institutions and non-banking financial institutions to start Payment Banks/Small Finance Banks. The need arises to study the impact of Small Financial banks on financial inclusion.

\section{Review of literature:}

IIMB-WP No. 474 - In this paper Prof. Charan Singh RBI Chair Professor Economics \& Social Science Indian Institute of Management Bangalore has examined as the majority of the rural population is still not included in the inclusive growth, the concept of financial inclusion becomes a challenge for the Indian economy. Many concerted measures are initiated by the Reserve Bank of India and Government of India in favor of financial inclusion but the impact of these did not yield satisfactory results. He focused on utilizing the existing resources such as Mobile phones, Banking Technologies, India Post Office, Fair Price Shops and Business Correspondents thereby making it more efficient and user friendly for the interest of the rural population as well as the formal sector.

Purvi Shah and Medha Dubhashi, explained about the origin of the current approach to financial inclusion can be traced to the United Nations initiatives, which broadly described the main goals of inclusive finance as access to a range of financial services including savings, credit, insurance, remittance and other banking/payment services to all 'bankable' households and enterprises at a reasonable cost. The availability of quality financial services in rural areas is extremely important for the growth of the economy as this will enable the large number of rural households to fund the growth of their livelihoods. The growth of the economy is dependent on the growth of the rural market in the country. 
Rakesh Mohan and Partha Ray, state the future areas for development in the Indian financial sector would include further reduction of public ownership in banks, expansion of the contractual savings system through more rapid expansion of the banking systems,

Dr. R Ramakrishnan, he explains Differentiated Banks and Financial Inclusion There are enormous unmet potential lying in the rural areas for financial institutions. If financial institutions could successfully tap this potential there would be a win-win ${ }^{\text {ee }}$ situation for institutions and people. Financial inclusion bringing more people into the formal financial system by giving individuals tools to cope with everyday needs and increases the likelihood of their access to education, health services and employment.

Shri R. Gandhi, Deputy Governor at Sastra University, Campus Kumbakonam on April 18, 2015. Assistance provided by Ms Sara Rajendra Kumar is gratefully acknowledged. Express thoughts about what are issues and challenges faced by differentiated banks and it is crucial that the financial system is flexible and competitive to cope with multiple objectives and demands made on it by various constituents of the economy. However, in a country like India where there exists differentiated markets and consumer groups, the concept may have to be contextualized according to the needs of the customers. As regards the health of the differentiated banks, there is a need for creating a balance between long term sustainability and the financial inclusion goals.

Dr. Dhiraj Jain Associate Professor, Pacific Business School, Udaipur "Differentiated Bank Licenses: Emergence of a New Bank Structure". In this article he says about the issue of new bank licenses is very sensitive as India is an under banked country. The idea behind the licensing regime was that the basic principles of bank ownership and governance, viz. the 'fit and proper' criteria, are not diluted. The industrial licensing has long been scrapped but licensing in the banking industry is still there and the RBI decides who is 'fit and proper' to run a bank.

During Phase I, 74,414 unbanked villages with population more than 2,000 were identified and allotted to various banks through SLBCs for coverage through various modes, that is, branches, BCs or other modes such as ATMs and satellite branches, etc. All these unbanked villages have been covered by opening banking outlets comprising 2,493 branches, 69,589 BCs and 2,332 through other modes. 
In Phase II, under the roadmap for provision of banking outlets in unbanked villages with population less than 2,000, about 4,90,000 unbanked villages have been identified and allotted to banks for coverage in a time bound manner by March 31, 2016. As per the progress reports received from State level banker's committees (SLBCs), banks had opened banking outlets in 1,83,993 unbanked villages by March 2014, comprising 7,761 branches, 163,187 Business Correspondents (BCs) and 13,045 through other modes. The Reserve Bank is closely monitoring the progress made by the banks under the roadmap.

A Government of India's High Level Committee on Financial Sector Reforms headed by Dr Raghuram Rajan has submitted its report in 2008 titled “A Hundred Small Steps”. Among its various recommendations, the Committee recommended that there is a need for paradigm shift in the strategy for financial inclusion. It said the emphasis should be shifted from largebank-led, public-sector-dominated, mandate-ridden, branch-expansion-focused strategy. It said the poor need efficiency, innovation, and value for money which can come from motivated financiers who have low cost structure and thus see poor as profitable, but who also have the capacity to make decisions quickly, and with minimum paperwork. It therefore recommended that entry to private, well-governed, deposit-taking small finance banks be allowed.

Addressing the $\mathbf{3 4}^{\text {th }}$ Bankers Conference (BANCON 2013), the erstwhile Finance Minister Mr. P. Chidambaram expressed concern about the fact that most of our banks were clones of others rather than having a differentiated identity. Differentiated banking licenses are important as such banks would be innovative in their structure and would lead to better attainment of the financial objectives. The failure of various companies in not getting a banking license from the RBI and being asked to go back to the drawing board and draft a new application for differentiated permits instead of a full license is a clear indication from the RBI of its objective of a greater financial inclusion. According to one of the reports, the differentiated banking activity licenses issued to Regional Rural Banks and Local Area Banks (LABs) could not achieve the objectives for which they were set out which prompted authorities to call for larger size banks to go for rapid financial inclusion in a time bound and phased manner.

\section{Objectives of the study:}

- To study the impact of Small Finance Banks on financial inclusion.

- To know the financial performance of select Small Finance Banks. 


\section{Methodology:}

The present study is based on the secondary data which is collected from Annual Reports, Banks Websites, books, journals and news papers. Simple statistical tools have been used to analyze the collected data.

\section{Limitations:}

- The study is limited to only select Small Finance Banks.

- The research is restricted to know the impact of Small Finance Banks on financial inclusion only.

\section{Differentiated Banking Licenses}

Differentiated licensing refers to the system of different licenses for different sub sectors of the banking sector such as Limited Banking License, Commercial Banking License etc. There are many countries where different licenses are issued for Commercial or Saving Banks, Rural Banks or for Credit Unions. In certain countries, no distinction is made between domestic and foreign banks. Thus, there is no widely accepted recommended model available internationally. Advocates of this system say that many banks keep the plain vanilla banking as a small and a necessary adjunct. Banks providing services to retail customers have different skill sets and risk profiles as compared to banks which mainly deal with large corporate clients and hence there should be a system of differentiated licensing. These differentiated banks would specialize only in one area of banking, but at the same time this could lead to higher risk and higher asset-liability mismatches. The Nachiket Mor panel has provided certain recommendations which could be useful.

The RBI-constituted Nachiket Mor Committee for financial inclusion first mooted the idea of having differentiated banks in the country. The panel's suggestions include specialized payment banks, retail banks, wholesale banks, infrastructure banks etc.

This differentiated bank structure could help new banks focus on niche lending opportunities and get a regulatory treatment different from other banks. Some countries have differentiated bank licensing regimes where licenses are issued specifically outlining the activities the licensed entity could undertake. Singapore has five different kinds of bank licenses - Full Bank, Qualifying Full Bank (QFB), Wholesale Bank (WB), Offshore Bank, and Representative Bank - while Hong Kong has a Three-tiered structure based on licenses, restricted licenses, and 
deposit taking companies. The regulator is further considering making bank licenses available on tap to those who fulfill the necessary conditions, rather than grant licenses only for a limited time. Though the RBI has not yet issued any clear cut guidelines on differentiated banks or 'ontap' licenses, the governor claims it will be done by the end of 2014. This initiative by the RBI would be able to fulfill the broader objective of financial inclusion and help make India a better banked country.

Issuance of License on the condition that the bank will open at least $25 \%$ of its branches in rural areas is a good way to strengthen banking services in those places. Use of technology and modern infrastructure facilities in addition to core banking solutions and various delivery channels will help improve customer service. While healthy competition among banks can be good for the customer in terms of products and services, it can prove counterproductive for banks, making some branches unviable.

Finally RBI in 2014 to gives the in principle approval were issued to 11 organization as payment banks, 10 organization as small finance banks and 2 micro finance institution as banks to enhance the financial inclusion.

Since April 2014, the Reserve Bank of India has granted 23 banking licenses to new players two were given the in principle approval to micro finance institution are IDFC and Bandhan as banks (April 2, 2014), 11 were issued payments banks licenses to Aditya Birla Nuvo, Fino PayTech, National Securities Depository, Reliance Industries, Dilip Shantilal Shanghvi, Tech Mahindra, Vodafone M-pesa, Airtel M Commerce, Department of Posts, Vijay Shekhar Sharma, Cholamandalam Distribution (August 19, 2015) and 10 were given licenses for small finance banks to Au Financiers, Suryoday Micro Finance, Capital Local Area Bank, Disha Microfin, Equitas Holdings, ESAF Microfinance and Investments, Ujjivan Financial Services, Janalakshmi Financial Services, Utkarsh Micro Finance, RGVN (North East) Microfinance (September 16, 2015). The niche banks - small finance and payments banks -have been set up to further the regulator's objective of deepening financial inclusion.

\section{Differentiated Bank Licensing Policy}

The RBI received 41 applications for payments bank license and 72 for small finance bank license. The RBI received recommendations from the external advisory committee on 
payments banks chaired by former banker Nachiket Mor and on small finance banks headed by Usha Thorat, former Deputy Governor of RBI. A number of corporate houses and a host of payment wallet companies have applied for payments bank licenses. Many banks have formed joint ventures with the applicants.

\section{Payments Banks}

On, August 19, 2015, Reserve Bank of India granted 'in-principle' approval to 11 applicants to start a payments bank. The Committee of the Central Board (CCB) of RBI has selected 11 entities that have the reach and the technological and financial strength to provide service to the customers and promote government's initiative of financial inclusion across the country. These banks are expected to reach customers mainly through their mobile phones rather than traditional bank branches. Out of these 11 applicants, Tech Mahindra Ltd, Cholamandalam Investment and Finance Co and billionaire Dilip Shanghvi have opted out.

\section{Small Finance Banks}

On September 17, 2015 The Reserve Bank of India (RBI) has granted in principle approval to 10 entities to set up small finance banks to provide basic banking services to small farmers and micro industries. The in-principle approval will enable these entities comply with the guidelines on Small Finance Banks and will be valid for 18 months.

\section{0 entities are:}

1. Au Financiers (India) Ltd

2. Capital Local Area Bank

3. Disha Microfin Private Ltd

4. Equitas Holdings P Limited

5. ESAF Microfinance and Investments Private Ltd

6. Janalakshmi Financial Services Private Limited

7. RGVN (North East) Microfinance Limited

8. Suryoday Micro Finance Private Ltd

9. Ujjivan Financial Services Private Ltd

10. Utkarsh Micro Finance Private Ltd.

As per RBI guidelines, the small finance banks can provide basic banking services in order to promote financial inclusion. It will include services like accepting deposits and lending to the 
unbanked sections such as micro business enterprises, small farmers, micro and small industries and unorganized sector entities.

\section{RBI Guidelines for Small Finance Banks:}

- Take small deposits and disburse loans

- Distribute mutual funds, insurance products another simple third-party financial products

- Lend $75 \%$ of their total adjusted net bank credit to priority sector

- Maximum loan size would be $10 \%$ of capital funds to single borrower, $15 \%$ to a group

- Minimum $50 \%$ of loans should be up to 25 lakhs

- Cannot lend to big corporate and groups

- Other financial activities of the promoter must not mingle with the bank

- It cannot set up subsidiaries to undertake non-banking financial services activities

- Cannot be a business correspondent of any bank

\section{Common Features of both Payments Banks and Small Finance Banks}

In regard to both Payments Banks and Small banks the draft guidelines have some common features. As per the guidelines, the minimum paid-up capital is Rs. 100 crore. Promoters' initial contribution will be at least 40 per cent to be locked in for five years. The banks can be promoted by individuals who have at least 10 years of experience / expertise in financial or banking field or by private sector companies or societies with good track record. The promoters will have to be resident Indians or owned and controlled by resident Indians. They will have to conform to stringent 'fit and proper' criteria.

In case of small banking finance existing MFIs, NBFCs or LABs can opt for conversion, and that of payment banks existing PPIs can opt for conversion.

The capital adequacy framework is same for both type of banks -- Minimum Capital Requirement (15 per cent) and Common Equity Tier 1 (6 per cent). 


\section{Analysis and Interpretation:}

Data as per RBI Census: Quantta Analytics as on Sept $2017^{1}$

(Ref. Rural Report Card "The Branches have not spread much" Business Lines, Sept $9^{\text {th }}$ 2017)

Table 1: Banks in India by Population

(Just 1/3 of the banks in India are located in rural areas)

\begin{tabular}{|l|l|l|l|l|}
\hline Particulars & Rural & Semi Urban & Urban & Metropolitan \\
\hline Banks in India by Population & 33.88 & 26.84 & 18.69 & 20.59 \\
\hline Population per Bank & & & & \\
\hline
\end{tabular}

Note: Based on the population size, the location of a bank branch is classified as under

Rural: Population less than 10,000

Semi Urban: Above 10,000 and less than 1lakh

Urban: Above 1lakh and less than 10lakh

Metropolitan: 10lakh and above

Table 2: Banks by Region

\begin{tabular}{|c|l|l|l|l|l|l|}
\hline & Central & Eastern & $\begin{array}{l}\text { North- } \\
\text { Eastern }\end{array}$ & Northern & Southern & Western \\
\hline $\begin{array}{c}\text { Banks by } \\
\text { Region }\end{array}$ & 11,844 & 10,161 & 1,685 & 9,041 & 10,517 & 5,817 \\
\hline $\begin{array}{c}\text { Population } \\
\text { per Bank by } \\
\text { Region }\end{array}$ & 19,400 & 19400 & 22,300 & 10,900 & 11,800 & 15,800 \\
\hline
\end{tabular}


Table 3: Banks in rural India by bank group

\begin{tabular}{|l|l|}
\hline Small Finance Banks & $0.24 \%$ \\
\hline Local area Banks & $0.02 \%$ \\
\hline Foreign Banks & $0.02 \%$ \\
\hline National Banks & $42.44 \%$ \\
\hline New Private Sector Banks & $7.03 \%$ \\
\hline SBI and its associates & $16.02 \%$ \\
\hline Regional rural Banks & $30.47 \%$ \\
\hline Other Public Sector Banks & $0.85 \%$ \\
\hline Old Private Sector Banks & $2.91 \%$ \\
\hline
\end{tabular}

\section{Interpretation:}

- As per the quanta analysis the bank branches have not spread much in rural areas.

- Only $1 / 3$ of branches spread in rural areas.

- The population served per bank is way higher in rural areas compared to urban branches.

- This report represent banks by located based on region in central India has the most number of rural branches and in the north eastern region is very less spread bank branches to rural areas.

- A majority of the banks in rural areas are in the public sector banks.

- North eastern region is the worst in terms of population served

\section{Conclusion}

There is enormous unmet potential demand lying in the rural areas and other unbanked centres which needs to be tapped. To tap this unmet demand for financial services, it is felt that it is worth experimenting on new types of institutions for financial inclusion. However, in a country like India where there exists differentiated markets and consumer groups, the concept may have to be contextualized according to the needs of the customers. As regards the health of the differentiated banks, there is a need for creating a balance between long term sustainability and the financial inclusion goals. It is becoming increasingly apparent that addressing financial exclusion will require a holistic approach on the part of the banks in creating awareness about financial products, education, and advice on money management, debt counseling, savings and affordable credit. 
The banks would have to evolve specific strategies to expand the outreach of their services in order to promote financial inclusion. Still Reserve Bank of India and Government of India need to more concentration on to extent the financial services to rural areas and to require encouragement of awareness programme towards ensuring access to financial services and timely and adequate credit where needed by vulnerable groups such as weaker sections and low income groups at an affordable cost.

\section{Reference Books:}

1. Dr. M.S.V. Prasad and Dr. G.V. Satya Sekhar (2016) "Financial Inclusion in India" Gitam Institute of Management, Gitam University.

2. Indian Institute of Banking and Finance (IIBF) (Jan 2015) "Principles and Practice of Banking " Macmillan education, $3^{\text {rd }}$ edition.

3. M.N. Gopinath (2015) "Banking Principles and Operation" Snow white publication, $6^{\text {th }}$ edition.

4. Sukhvinder (2012) "Banking law and practice" S. Chand higher education academy, 1st edition, New Delhi.

\section{References Journals and Articles:}

1. Chakrabarty K.C (2013), "Financial Inclusion in India: Journey So Far and the Way Forward”, Key note address at Finance Inclusion Conclave Organised by CNBC TV 18 at New Delhi.

2. Chakrabarty K.C (2013), "Revving up the Growth Engine through Financial Inclusion", address at the 32th SKOCH Summit held at Mumbai.

3. Department of Finance,( 2013) Gitam Institute of Management, Gitam University. "Financial Inclusion in India: Challenges and Strategies". 1st ed., Excel Books, New Delhi.

4. Dr. Dhiraj Jain (June 2014) Associate Professor, Pacific Business School, Udaipur Pacific Business Review International Volume 6, Issue 12, Udaipur.

5. Lazar Daniel and P. Palanichamy (Mar 2014) Micro Finance and Poverty Eradication New Century Publications, Pondicherry University, Pondicherry, India.

6. Narayan Chandra Pradhan (2013), "Persistence of Informal Credit in Rural India: Evidence from All-India Debt and Investment Survey and Beyond”, RBI Working Paper Series, WPS (DEPR): 5/2013 
7. Raghuram G. Rajan (2009), "A Hundred Small Steps - Report of the Committee on Financial Sector Reforms".

8. Rangarajan C (2008), "Report of the Committee on Financial Inclusion"

9. Reserve Bank of India Banking Structure in India - The Way Forward accessed from rbidocs.rbi.org.in/rdocs/PublicationReport/Pdfs/DPBS27082013_F.pdf. 